\title{
Maturation of Sporangia of Phytophthora infestans Affecting the Rapidity of Indirect Germination
}

\author{
Norio SATO*
}

\begin{abstract}
The rapidity of indirect germination of the sporangia of Phytophthora infestans was investigated. Sporangial suspensions were prepared from the infected potato tuber slices or disks cultured for various periods at different temperatures. When the suspensions were incubated at $14^{\circ} \mathrm{C}$, optimum for indirect germination, sporangia from older cultures could germinate more quickly than those from younger cultures. Sporangia immediately after production could germinate only slowly, while almost all the sporangia aged by preincubation for $6 \mathrm{hr}$ or more at $22^{\circ} \mathrm{C}$ could germinate quickly within $1 \mathrm{hr}$ when postincubated at $14^{\circ} \mathrm{C}$. Therefore, it was considered that sporangial maturation by aging was essential to acquire the ability of indirect germination, and that matured sporangia could germinate quickly within about $1 \mathrm{hr}$ at $14^{\circ} \mathrm{C}$. Time required for sporangial maturation was remarkably affected by the air temperature during sporangial production and also by the incubation temperature after preparation of sporangial suspension. The shortest maturation time, about $6 \mathrm{hr}$, was found between 18 and $22^{\circ} \mathrm{C}$. Temperatures below $15^{\circ} \mathrm{C}$ remarkably slowed maturation, and temperatures of $26^{\circ} \mathrm{C}$ and above inhibited it. Matured sporangia quickly lost the ability of quick germination when the suspensions were incubated at $26^{\circ} \mathrm{C}$ or above.
\end{abstract}

(Received May 24, 1993)

Key words: Phytophthora infestans, sporangial maturation, indirect germination, potato late blight.

\section{INTRODUCTION}

Phytophthora infestans (Mont.) de Bary causes the important diseases, late blight of potato and tomato. Sporangia of the fungus can germinate either indirectly releasing zoospores or directly growing germ tubes. In water direct germination of young sporangia, less than a few days old, occurs very slowly, usually takes 1-2 days, and the proportion of germination is usually low, while indirect germination occurs rapidly and some sporangia release zoospores within $1 \mathrm{hr}^{3}$. Zoospores play a very important role on the disease development because they can swim in water to infection sites of plants and can germinate quickly ${ }^{3,4,6,7}$. Therefore, for inoculum potential, not only sporangial production but also the proportion and rapidity of indirect germination are very important factors. It has been known that temperatures of $9-13^{\circ} \mathrm{C}$ were the optimum for indirect germination whereas $23-24^{\circ} \mathrm{C}$ inhibitory to $i t^{1,3,6)}$, and the proportion of germination was very variable, sometimes high but sometimes low even when sporangial suspensions were incubated for 1-2 days at the optimum temperatures ${ }^{1,2,3,6)}$. The delicate nature of indirect germination seemed to disturb further progress of physiological research. Perhaps, distilled water and the tap water used by the previous workers might not be very favorable for indirect germination, because in the tap water of Hokkaido Natl. Agric. Exp. Stn. the proportion of germination was always high, which enabled a series of detailed investigations on sporangial germina-

* Hokkaido National Agricultural Experiment Station, Hitsujigaoka-1, Toyohira-ku, Sapporo 062, Japan＼cjkstart北 海道農業試験場 
tion.

This paper reports some factors affecting the rapidity of indirect germination. Since direct germination was always less than a few percent, it was neglected and in this report hereafter indirect germination will be described simply as germination except for special notices. A part of the results was briefly referred to elsewhere before ${ }^{8)}$.

\section{MATERIALS AND METHODS}

Sporangial production. An isolate (H-0) of $P$. infestans, race 0 and $\mathrm{Al}$ mating type, was maintained on potato tuber slices of cultivar Irish Cobbler by weekly inoculation. To produce sporangia, two different cultures, tuber-slice and -disk cultures, were used (Fig. 1). In the tuber-slice cultures, slices of 8-10 mm thick were placed on the V-shaped glass rods on the moist newspaper sheet in a petri dish (18 cm dia.) and sprayed with a dilute sporangial suspension (about 500 sporangia/ml). The petri dishes were kept in a temperature-controlled room at about $18^{\circ} \mathrm{C}$. Sporangial production was few in 5 days but abundant in 6 and 7 days (Fig. 1-A). In the tuber-disk cultures, disks were cut out from the 5-day-old tuber-slice cultures by a cork borer ( $20 \mathrm{~mm}$ dia.) and the sporulating surface tissues of about $1 \mathrm{~mm}$ thick were removed by a razor for making a disk of about 6-8 $\mathrm{mm}$ thick (Fig. 1-B and C). After washing in running tap water and gently wiping with a paper towel, four to six tuber disks were placed on the wavy folded filter papers in a $9 \mathrm{~cm}$ petri dish, in which a $3 \mathrm{~cm}$ dish containing water and a filter-paper wick was placed to keep a high moisture condition (Fig. 1-D). They were kept in electric incubators at various temperatures between 10 and $26^{\circ} \mathrm{C}\left( \pm 1^{\circ} \mathrm{C}\right)$. Resporulation on the tuber disks began in about $6-8 \mathrm{hr}$ and the amount of sporangia increased with time as shown in Table 1.

Preparation of sporangial suspension and incubation for germination. The tap water from the well of Hokkaido Natl. Agric. Exp. Stn. was used to prepare sporangial suspensions. Sporangia

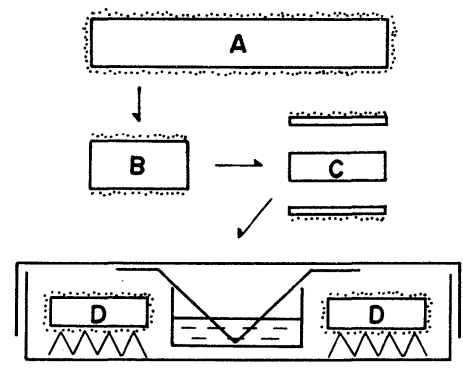

Fig. 1. Methods for obtaining the sporangia of Phytophthora infestans. The sporangia used for germination tests were collected either from potato tuber-slice cultures (A) or tuber-disk cultures (D).

Table 1. Effect of air temperature on sporangial production of Phytophthora infestans on potato tuber-disk cultures $^{\mathrm{a})}$

\begin{tabular}{|c|c|c|c|c|c|}
\hline \multirow{3}{*}{$\begin{array}{l}\text { Air temp. } \\
\quad\left({ }^{\circ} \mathrm{C}\right)\end{array}$} & \multicolumn{5}{|c|}{ No. of sporangia from 12 tuber-disk cultures $\left(\times 10^{4}\right)$} \\
\hline & \multicolumn{5}{|c|}{ Time (hr) of culture incubation } \\
\hline & 12 & 18 & 24 & 36 & 48 \\
\hline 10 & 0.02 & 0.2 & 1.0 & 2.8 & 7.5 \\
\hline 12 & 0.1 & 1.1 & 2.9 & 6.4 & 12.2 \\
\hline 15 & 0.5 & 4.6 & 13.6 & 26.6 & 57.8 \\
\hline 18 & 0.9 & 8.8 & 17.2 & 30.8 & 97.6 \\
\hline 20 & 0.7 & 11.5 & 19.1 & 51.8 & 93.6 \\
\hline 22 & 0.9 & 12.8 & 20.3 & 65.8 & 113.8 \\
\hline 24 & 0.6 & 7.6 & 15.6 & 36.8 & 35.9 \\
\hline 26 & 0.2 & 1.7 & 2.9 & 5.2 & 3.7 \\
\hline
\end{tabular}

a) Average of three experiments. The average coefficient of variation was 0.66 . 
were suspended by shortly dipping of the cultures in water of $22-24^{\circ} \mathrm{C}$. The suspension was filtered through a gauze to remove mycelia, and after twice centrifugation $(1,000 \mathrm{rpm}, 1 \mathrm{~min})$ for washing, the precipitated sporangia were resuspended in water at the concentration of $2.0 \times 10^{4}$ or less sporangia $/ \mathrm{ml}$. The suspension was dispensed into three test tubes ( $15 \mathrm{~mm}$ dia.), 2-3 $\mathrm{ml}$ per each, and incubated in a water bath at $14^{\circ} \mathrm{C}\left( \pm 0.2^{\circ} \mathrm{C}\right)$ either immediately or after pre-incubation at different temperatures for various periods of time. The suspensions were kept undisturbed except for a brief agitation when sampling.

Determination of the proportion of germination. A small aliquot $(0.2-0.3 \mathrm{ml})$ of suspension was taken from the test tubes, and added with a drop of $10 \%$ formalin to stop further germination. The proportion of the sporangia which had already released zoospores and just been releasing them was determined by observing at least 100 sporangia under a microscope, and the average percentage of three test tubes was used to indicate the proportion of germination in a suspension.

\section{RESULTS}

\section{Relation of sporangial age to the time required for germination}

Sporangia from the tuber-slice cultures 5, 6 and 7 days after inoculation were used to prepare suspensions. Either immediately after preparation or after pre-incubation for $24 \mathrm{hr}$ at $22^{\circ} \mathrm{C}$, the suspensions were incubated at $14^{\circ} \mathrm{C}$, and the proportion of germination was determined at intervals. The results are shown in Fig. 2. In the suspensions immediately incubated at $14^{\circ} \mathrm{C}$, the rapidity of germination fairly differed depending on culture period. The longer the culture period was, the more rapid the germination. The proportions of germination for the first $1 \mathrm{hr}$ in the suspensions from 5-, 6- and 7-day-old cultures were 7,19 , and $34 \%$, respectively. On the contrary, in the pre-incubated suspensions germination occurred rapidly irrespective of the culture period, and the proportion reached about $90 \%$ in the first 1

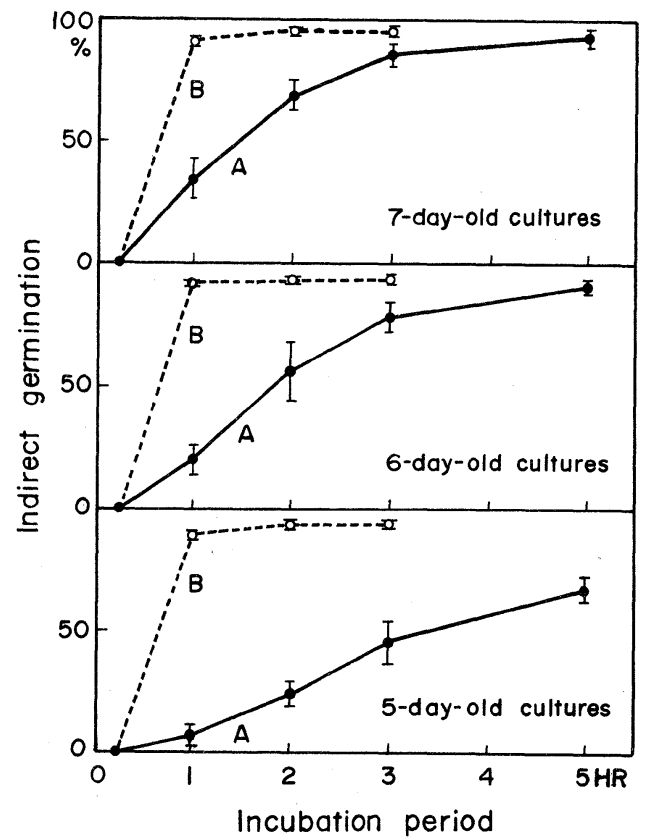

Fig. 2. Effect of the culture period to produce sporangia of Phytophthora infestans and the pre-incubation of sporangial suspensions for $24 \mathrm{hr}$ at $22^{\circ} \mathrm{C}$, on the rapidity of indirect germination. The sporangial suspensions prepared from tuber-slice cultures were incubated at $14^{\circ} \mathrm{C}$ either immediately (A) or after the pre-incubation (B). Each value indicates the average of five (A) and three (B) experiments, and the vertical bars show standard deviations. 


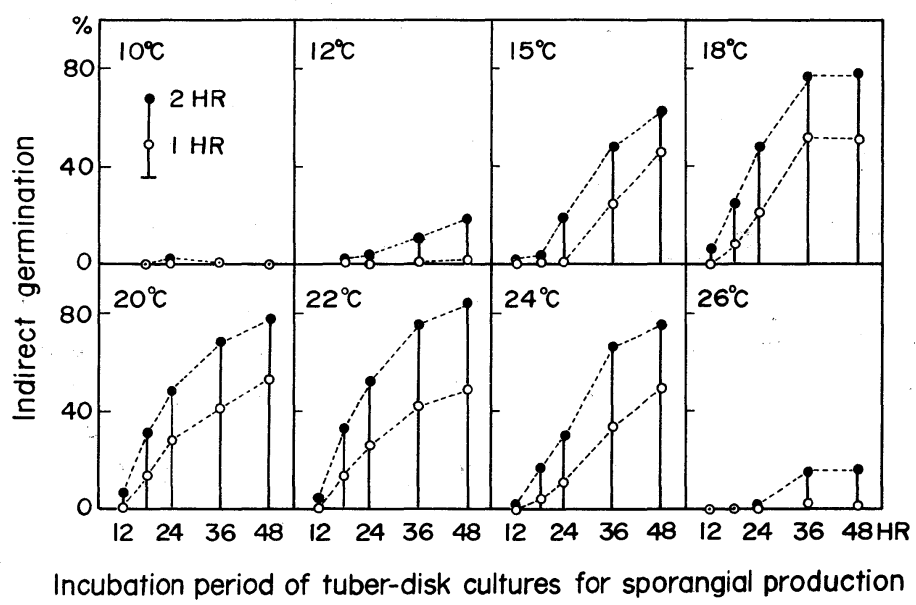

Fig. 3. Effect of the air temperature and period of incubation of tuber disk cultures of Phytophthora infestans to produce sporangia on the rapidity of indirect germination of the sporangia in water at $14^{\circ} \mathrm{C}$. Each value indicates the average of three experiments.

$\mathrm{hr}$. When the suspensions of newly produced sporangia from the infected tuber disks cultured for less than $12 \mathrm{hr}$ were immediately incubated at $14^{\circ} \mathrm{C}$, the sporangia germinated only slowly. Apparently sporangial age greatly affected the rapidity of germination and some period of aging appeared to be essential to acquire the ability of quick germination. Hereafter the author calls the physiological process to acquire the ability of quick germination as 'maturation'.

\section{Effect of air temperature on sporangial maturation}

Sporangia from the infected tuber disks cultured for the various periods of $12,18,24,36$ and $48 \mathrm{hr}$ at the different air temperatures of $10,12,15,18,20,22,24$ and $26^{\circ} \mathrm{C}$, were used to prepare suspensions. The suspensions were incubated at $14^{\circ} \mathrm{C}$ immediately after preparation and the proportion of germination was determined after incubation for 1, 2, 3, 4, 6 and $24 \mathrm{hr}$. Irrespective of the different conditions of sporangial production, almost all sporangia germinated (av. 95.1\%) within $24 \mathrm{hr}$. However, the proportions within the first few hr differed remarkably depending on the conditions of sporangial production, and so, only the proportions in the first 1 and $2 \mathrm{hr}$ are shown in Fig. 3. Again, the culture period, or sporangial age, greatly affected the rapidity of germination. Newly produced sporangia from the youngest cultures at each temperature could not germinate quickly within $1 \mathrm{hr}$. As the culture period increased, the proportion of quickly germinative sporangia, or matured ones, increased. Air temperature during sporangial production also greatly affected sporangial maturation. Ten ${ }^{\circ} \mathrm{C}$ appeared to be almost completely inhibitory to maturation: quickly germinative sporangia were not found even in the sporangia from the oldest cultures. Twelve ${ }^{\circ} \mathrm{C}$ and $26^{\circ} \mathrm{C}$ were also strongly inhibitory to maturation. At $15^{\circ} \mathrm{C}$ matured sporangia began to appear from the 24-hr-old cultures. At $24^{\circ} \mathrm{C}$ the appearance of matured sporangia was a little earlier than at $15^{\circ} \mathrm{C}$. At 18,20 and $22^{\circ} \mathrm{C}$ matured sporangia began to appear from the 12-hr-old cultures, when the oldest sporangia were about $6 \mathrm{hr}$ old, and the proportion increased rapidly. Therefore, it was considered that air temperatures between 18 and $22^{\circ} \mathrm{C}$ were the optimum for sporangial maturation, and that the shortest time required for maturation at these temperatures was about $6 \mathrm{hr}$. At those favorable temperatures for maturation including 15 and $24^{\circ} \mathrm{C}$, the proportion of matured sporangia reached aböut $50 \%$ when the infected tuber disks were cultured for $48 \mathrm{hr}$.

\section{Effect of water temperature on sporangial maturation}

Newly produced sporangia from the infected tuber disks cultured for $16 \mathrm{hr}$ at $24^{\circ} \mathrm{C}$ were used to prepare suspensions. The suspensions were pre-incubated at the temperatures of $10,14,18,22,24$, and $26^{\circ} \mathrm{C}$. At intervals small aliquots were taken and post-incubated for $1 \mathrm{hr}$ at $14^{\circ} \mathrm{C}$ to determine the proportion of matured sporangia. The results are shown in Fig. 4. Water temperature also greatly affected sporangial maturation. As matured sporangia always included small proportions of a little 


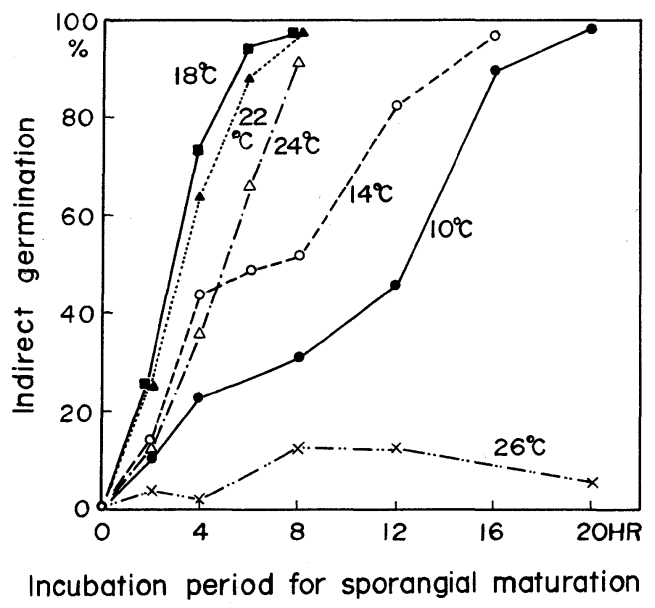

Fig. 4. Effect of water temperature on maturation of the sporangia of Phytophthora infestans. The suspensions of newly produced sporangia from the infected tuber disks cultured for $16 \mathrm{hr}$ at $24^{\circ} \mathrm{C}$ were pre-incubated at the designated temperatures and then small aliquots of the suspensions were post-incubated for $1 \mathrm{hr}$ at $14^{\circ} \mathrm{C}$ to determine the proportion of indirect germination (matured sporangia). A representative result is shown.

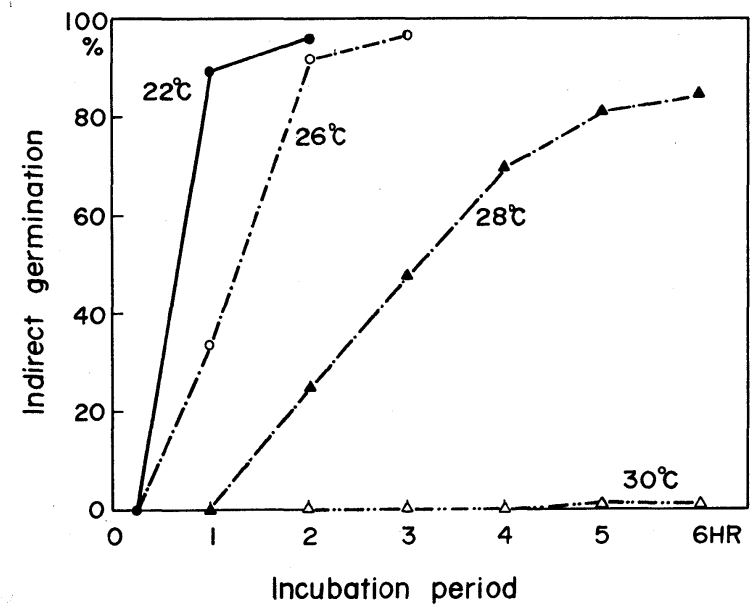

Fig. 5. Loss of the ability of quick germination of matured sporangia of Phytophthora infestans in water of comparatively high temperatures. The suspensions of matured sporangia pre-incubated for $2 \mathrm{hr}$ at the designated temperatures were post-incubated at $14^{\circ} \mathrm{C}$. A representative result is shown.

slower germinaters, the time required for attaining the level of $90 \%$ germination was presumed here to be the maturation time of the youngest sporangia in a suspension. Then the time required for maturation was about $6 \mathrm{hr}$ at both $18^{\circ} \mathrm{C}$ and $22^{\circ} \mathrm{C}, 8 \mathrm{hr}$ at $24^{\circ} \mathrm{C}, 14 \mathrm{hr}$ at $14^{\circ} \mathrm{C}$, and $16 \mathrm{hr}$ at $10^{\circ} \mathrm{C}$. Twenty-six ${ }^{\circ} \mathrm{C}$ was rather inhibitory to maturation. Therefore, similarly to air temperature, the water temperatures between 18 and $22^{\circ} \mathrm{C}$ were also considered to be the optimum for sporangial maturation. However, the water temperature of $10^{\circ} \mathrm{C}$ was not completely inhibitory to sporangial maturation unlike air temperature.

\section{Loss of the ability of quick germination of matured sporangia}

Sporangia from the infected tuber slices cultured for 7 days were used to prepare suspensions. After sporangial maturation was induced by incubation for $22 \mathrm{hr}$ at $22^{\circ} \mathrm{C}$, the suspensions were pre-incubated for $2 \mathrm{hr}$ at $22,26,28$ and $30^{\circ} \mathrm{C}$. Then the suspensions were post-incubated at $14^{\circ} \mathrm{C}$, and the proportion of 
germination was determined at intervals. The results are shown in Fig. 5 . The proportions of quickly germinative sporangia within $1 \mathrm{hr}$ in the suspensions pre-incubated at $22,26,28$ and $30^{\circ} \mathrm{C}$ were $89,34,0$ and $0 \%$, respectively. The rapidity of germination was remakably slowed down by the pre-incubation at $26^{\circ} \mathrm{C}$, and greatly slowed down at $28^{\circ} \mathrm{C}$, at which it took $5 \mathrm{hr}$ to attain $80 \%$ of germination. All the sporangia pre-incubated at $30^{\circ} \mathrm{C}$ could not start germination before $4 \mathrm{hr}$. The results suggest that the ability of quick germination of matured sporangia may be lost quickly at the temperatures above $26^{\circ} \mathrm{C}$.

\section{DISCUSSION}

The optimum water temperatures for indirect germination were reported as $12-13^{\circ} \mathrm{C}$ by Melhus ${ }^{6}$ and $\mathrm{Crosier}^{3)}$, and $9^{\circ} \mathrm{C}$ by Bohnen ${ }^{1)}$. However, the author used $14^{\circ} \mathrm{C}$ in the germination tests, because the temperature was best not only for the proportion but also the rapidity of germination. Distilled water has usually been used to test sporangial germination, in which nearly $100 \%$ of germination was sometimes achieved as shown by Bohnen ${ }^{1)}$, but usually it was not so favorable for germination as shown by Clark et al. $(30-80 \%)^{2)}$ and Crosier $(0-60 \% \text {, av. } 21 \%)^{3)}$. Such instability of germination has strongly disturbed the progress of physiological research on germination. On the contrary, the tap water of Hokkaido Natl. Agric. Exp. Stn. was very favorable for germination (av. 95.1\%), which enabled detailed investigations on sporangial germination.

The present results revealed that physiological properties of sporangia were variable by their ages and sporulating temperatures. Sporangia immediately after production didn't have the ability of quick germination, releasing zoospores within about $1 \mathrm{hr}$ at $14^{\circ} \mathrm{C}$, but acquired the ability by attaining maturity by aging. Air temperature during sporangial formation and water temperature after preparation of suspension showed similar effect on sporangial maturation. Temperatures between 18 and $22^{\circ} \mathrm{C}$ were the optimum for maturation and the time required for it was about $6 \mathrm{hr}$ at these temperatures. The ability of quick germination was lost rapidly when sporangial suspensions were incubated at the comparatively high temperatures above $26^{\circ} \mathrm{C}$. Such observations have not been carried out before.

Once Weille ${ }^{9)}$ also used the word maturation. He determined the total proportion of indirect and direct germinations after 2-3 days of incubation and called the both germinative sporangia as matured ones. Since indirect and direct germinations are quite different in physiological processes and should not be dealt with together, his use of the word maturation appears not to be adequate. Elsner et al. ${ }^{5)}$ also used the word maturation from the viewpoint of morphology. They designated those sporangia still exhibiting cytoplasmic continuity with their sporophores immature, and those ready for detachment mature. Cleavage vacuoles and well developed flagella were found in the cytoplasm of matured sporangia destined for indirect germination, while flagella resorption was found in the sporangia destined for direct germination. The relation between the morphological observations and the physiological process of maturation still remains unsolved.

Sporangial maturation will greatly affect the inoculum potential of the disease caused by $P$. infestans by affecting zoospore production. Therefore, further investigations on sporangial maturation under the field conditions will be required for the progress of the epidemiology of late blight of potato and tomato.

The author thanks Dr. D.H. Lapwood, Rothamsted Exp. Stn., England (retired), and also his colleagues, Dr. K. Takahashi and Mr. M. Kato, Hokkaido Natl. Agric. Exp. Stn., for critical reading of the manuscript.

\section{Literature cited}

1. Bohnen, K. (1963). Ein Verfahren zur Anzucht in vitro von Phytophthora infestans und die Verwendung des Pilzes im Sporenkeimtest zur Mittelprüfung. Phytopath. Z. 46:199-206.

2. Clark, M.C., Melanson, D.L. and Page, O.T. (1978). Purine metabolism and differential inhibition of spore germination in Phytophthora infestans. Can. J. Microbiol. 24 : 1032-1038.

3. Crosier, W. (1934). Studies in the biology of Phytophthora infestans (Mont.) de Bary. Cornell Univ. Agric. Exp. Stn. Memoir 155, pp. 40. 
4. Duniway, J.M. (1983). Role of physical factors in the development of Phytophthora diseases. In Phytophthora: Its Biology, Taxonomy, Ecology and Pathology (Erwin, D.C. et al. eds.). Amer. Phytopath. Soc. Press, Minnesota. pp. 175-187.

5. Elsner, P.R., Van der Molen, G.E., Horton, J.C. and Bowen, C.C. (1970). Fine structure of Phytophthora infestans during sporangial differentiation and germination. Phytopathology $60: 1765-1772$.

6. Melhus, I.E. (1915). Germination and infection with the fungus of the late blight of potato (Phytophthora infestans). Wisconsin Agric. Exp. Stn. Res. Bull. 37 : 1-64.

7. Sato, N. (1979). Effect of soil temperature on the field infection of potato tubers by Phytophthora infestans. Phytopathology 69 : 989-993.

8. Sato, N. (1983). Phytophthora : potato tuber rot. In Soil-borne Diseases of the Upland Crops in Hokkaido (Ui, T. ed.). Publication Committee for Soil-borne Diseases for the Upland Crops in Hokkaido, Sapporo. pp. 89-98 (in Japanese).

9. Weille, G.A. de (1963). An analysis of the variability of the germination power of conidia in a number of fungi belonging to the Peronosporales. Neth. J. Plant Path. 69: 115-131.

\section{和 文 摘 要}

\section{佐藤章夫：ジャガイモ疫病菌遊走子のうの成熟と間接発芽速度}

ジャガイモ疫病菌 (Phytophthora infestans) 遊走子のう(胞子)の懸濁液を調製して間接発芽(発芽) 適温の $14^{\circ} \mathrm{C}$ に置 いても, 形成直後の若い胞子は発芽に長時間を要した。懸濁液を発芽不適温度の $22^{\circ} \mathrm{C} に 6$ 時間以上置いて胞子の齢を 進めてから $14^{\circ} \mathrm{C}$ 㴘置くと, ほとんどすべての胞子が 1 時間以内に発芽した。したがって, 遊走子のうは形成直後は速 やかに発芽する能力を持たず，一定の時間を経過してその能力を獲得すると考えられたので，この現象を「成熟」と称

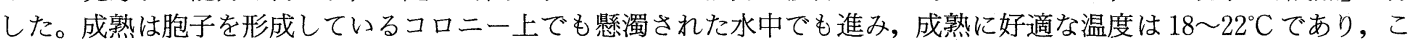
れらの温度における成熟所要時間はおよそ 6 時間であった。 $26^{\circ} \mathrm{C}$ 以上の高温と $15^{\circ} \mathrm{C}$ 末満の低温では成熟が抑制され た。また成熟胞子の持つ速やかに発芽する能力は, $26^{\circ} \mathrm{C}$ 以上の高温の水中では速やかに失われた。 